\title{
New peptides of the polycomb group protein enhancer of zeste homolog 2 with the potential to induce cancer-reactive cytotoxic $T$ lymphocytes in human leukocyte antigen- $\mathrm{A2}^{+}$prostate cancer patients
}

\author{
YUKOH ITOH $^{1}$, YOSHIHIRO KOMOHARA ${ }^{2}$, NOBUKAZU KOMATSU ${ }^{1}$, TAKAFUMI MINAMI ${ }^{3}$, \\ KOUJIRO SAITO ${ }^{4}$, MASANORI NOGUCHI ${ }^{4}, \mathrm{KYOGO} \mathrm{ITOH}^{1}$ and MAMORU HARADA ${ }^{1,2}$ \\ ${ }^{1}$ Department of Immunology, Kurume University School of Medicine, Kurume, Fukuoka; \\ ${ }^{2}$ Cancer Vaccine Development Division, Kurume University Research Center for Innovative \\ Cancer Therapy, Fukuoka; ${ }^{3}$ Department of Urology, Kinki University School of Medicine, Osaka; \\ ${ }^{4}$ Department of Urology, Kurume University School of Medicine, Kurume, Fukuoka, Japan
}

Received April 30, 2007; Accepted June 18, 2007

\begin{abstract}
The polycomb group protein enhancer of zeste homolog 2 (EZH2) is linked to aggressive prostate cancer and could be an appropriate target in specific immunotherapy. In this study, we attempted to identify EZH2-derived peptides that have the potential to generate cancer-reactive cytotoxic $\mathrm{T}$ lymphocytes (CTLs) in human leukocyte antigen (HLA)$\mathrm{A} 2^{+}$prostate cancer patients. Twelve EZH2-derived peptides were prepared based on the HLA-A2 binding motif. These peptide candidates were screened first by their ability to be recognized by immunoglobulin $\mathrm{G}(\mathrm{IgG})$, and then by their ability to induce peptide-specific cytotoxic $\mathrm{T}$ lymphocytes (CTLs). As a result, five EZH2 peptides recognized by IgG (EZH2 120-128, EZH2 165-174, EZH2 569-577, EZH2 665674, and EZH2 699-708) were frequently detected in the plasma of prostate cancer patients. Among them, the EZH2 120-128 and EZH2 165-174 peptides effectively induced HLA-A2-restricted and cancer-reactive CTLs from prostate cancer patients. The cytotoxicity was mainly dependent on EZH2 peptide-specific and HLA-A2-restricted CD8 ${ }^{+} \mathrm{T}$ cells. These results indicate that these EZH2 120-128 and EZH2 165-174 peptides could be promising candidates in peptidebased immunotherapy for HLA-A2+ prostate cancer patients.
\end{abstract}

\section{Introduction}

Prostate cancer is one of the most frequent cancers diagnosed in the elderly male population (1). Prostate cancer frequently

Correspondence to: Dr Mamoru Harada, Department of Immunology, Shimane University Faculty of Medicine, 89-1 Enyacho, Izumo, Shimane 693-8501, Japan

E-mail: haramamo@med.shimane-u.ac.jp

Key words: prostate cancer, enhancer of zeste homolog 2, cytotoxic $\mathrm{T}$ lymphocytes, peptide, human leukocyte antigen-A2 metastasizes to bone, and androgen withdrawal therapy has been applied for such patients. However, there is no efficient therapy against hormone-refractory and metastatic prostate cancer. Therefore, novel therapeutic modalities for the treatment of hormone refractory prostate cancer are urgently needed, and immunotherapy appears to be one candidate. Identification of useful target molecules for specific immunotherapy against prostate cancer has been attempted $(2,3)$.

Enhancer of zeste homolog 2 (EZH2) has been reported to be overexpressed in metastatic prostate cancer (4). EZH2 is a polycomb group protein homologue to the Drosophila enhancer of zeste, and is involved in gene silencing (5). Dysregulation of this gene-silencing machinery can lead to cancer $(4,6-8)$. EZH2 participates in epigenetic gene silencing by directly controlling DNA methylation (9). In addition, EZH2 has been reported to be a tumor-associated antigen (10). These lines of evidence suggest that EZH2 could be a promising target molecule in specific immunotherapy for prostate cancer patients. We previously identified EZH2-derived peptide epitopes which can be useful for human leukocyte antigen (HLA)-A24+ prostate cancer patients (11). In this study, we further attempted to identify EZH2-derived peptides that have the potential to generate cancer-reactive cytotoxic $\mathrm{T}$ lymphocytes (CTLs) in HLA-A2+ prostate cancer patients because of the higher worldwide frequency of this allele (12).

\section{Materials and methods}

Patients. All prostate cancer patients in this study provided their informed consent before enrollment. None of these participants was infected with human immunodeficiency virus (HIV). Twenty milliliters of peripheral blood was obtained, and the peripheral blood mononuclear cells (PBMCs) were prepared by Ficoll-Conray density gradient centrifugation. The expression of HLA-A2 molecules on the PBMCs of cancer patients was determined by flow cytometry. In some patients, the HLA-A2 genotypes were determined using sequence-specific oligonucleotide DNA typing after PCR. 
Cell lines. T2 is an HLA-A*0201-expressing cell line. PC93 is an HLA-A2-negative prostate cancer cell line which was established by Dr K. Ohiishi, Kyoto University. PC93-A2 is a subline which was stably transfected with the HLA-A*0201 gene (13). All cell lines were maintained in RPMI-1640 medium (Gibco BRL, Grand Island, NY) supplemented with $10 \%$ FCS.

Peptides. Twelve EZH2-derived peptides (Table I) were prepared based on the HLA-A2 binding motif (14). All peptides were of $>90 \%$ purity and were purchased from Biologica Co., Nagoya, Japan. Influenza (Flu) virus-derived (GILGFVFTL) and HIV-derived peptides (SLYNTVATL) with the HLA-A2 binding motif were used as controls. All peptides were dissolved with DMSO at a dose of $10 \mathrm{mg} / \mathrm{ml}$.

Detection of peptide-specific IgG. Peptide-specific IgG levels in the plasma were measured by the Luminex ${ }^{\mathrm{TM}}$ system as previously reported (15). In brief, plasma was incubated with $25 \mu 1$ of peptide-coupled color-coded beads for $2 \mathrm{~h}$ at room temperature on a plate shaker. After incubation, the mixture was washed with vacuum manifold apparatus and incubated with $100 \mu 1$ of biotinylated goat anti-human IgG ( $\gamma$ chainspecific) for $1 \mathrm{~h}$ at room temperature. The plate was then washed, followed by the addition of $100 \mu 1$ of streptavidin$\mathrm{PE}$ into each well, and was incubated for $30 \mathrm{~min}$ at room temperature on a plate shaker. The bound beads were washed three times followed by the addition of $100 \mu 1$ of Tween-PBS into each well. Of the sample, $50 \mu 1$ was detected using the Luminex $^{\mathrm{TM}}$ system.

Assay for peptide-specific CTLs in PBMCs. The assay for the detection of peptide-specific CTLs in PBMCs was performed according to a previously reported method (16). In brief, PBMCs $\left(1 \times 10^{5}\right.$ cells/well) were incubated with $10 \mu \mathrm{g} / \mathrm{ml}$ of each peptide in a U-bottom-type 96-well microculture plate (Nunc, Roskilde, Denmark) at a volume of $200 \mu 1$ of culture medium. The culture medium consisted of 45\% RPMI-1640, 45\% AIM-V medium (Gibco BRL), 10\% FCS, $100 \mathrm{U} / \mathrm{ml}$ of interleukin (IL)-2, and 0.1 mM MEM nonessential amino acid solution (Gibco, BRL). Half of the culture medium was removed and replaced with new medium containing a corresponding peptide $(20 \mu \mathrm{g} / \mathrm{ml})$ every 3 days. On the 15 th day of culture, the cultured cells were separated into 4 wells, two of which were used for EZH2 peptide-pulsed T2 cells, and the other two of which were used for the HIV peptide-pulsed T2 cells. After an 18-h incubation period, the supernatants were collected and the level of IFN- $\gamma$ was determined by ELISA.

Cytotoxicity assay. After in vitro stimulation with the EZH2 peptides, the peptide-stimulated PBMCs were additionally cultured with $100 \mathrm{U} / \mathrm{ml} \mathrm{IL-2}$ for approximately 10 days in 96-round-well plates in order to obtain a sufficient number of cells to carry out a cytotoxicity assay. For cytotoxicity assay, $\mathrm{CD}^{+} \mathrm{T}$ cells were purified using a CD8 isolation kit (DYNAL, Oslo, Norway). These cells were tested for cytotoxicity against both PC93 and PC93-A2 by a 6-h ${ }^{51} \mathrm{Cr}$-release assay. Two thousand ${ }^{51} \mathrm{Cr}$-labeled cells per well were cultured with effector cells in 96-round-well plates at the indicated effector/target
Table I. EZH2-derived peptide candidates binding to the HLA-A2 molecules.

\begin{tabular}{cccc}
\hline Position & Amino acid sequence & Length & Binding score \\
\hline $48-56$ & KILERTEIL & 9 & 31 \\
$95-104$ & VIPLKTLNAV & 10 & 37 \\
$120-128$ & FMVEDETVL & 9 & 119 \\
$165-174$ & FINDEIFVEL & 10 & 105 \\
$222-230$ & KIFEAISSM & 9 & 83 \\
$438-446$ & SMFRVLIGT & 9 & 46 \\
$569-577$ & KQCPCYLAV & 9 & 37 \\
$661-669$ & YMCSFLFNL & 9 & 3598 \\
$665-674$ & FLFNLNNDFV & 10 & 3190 \\
$668-677$ & NLNNDFVVDA & 10 & 43 \\
$699-708$ & VMMVNGDHRI & 10 & 47 \\
$729-737$ & SQADALKYV & 9 & 366 \\
\hline
\end{tabular}

The peptide binding score was calculated based on the predicted half-time of the HLA-A2 molecules as obtained from the website (Bioinformatics and Molecular Analysis Section, Computed Bioscience and Engineering Laboratory, Division of Computer Research and technology, NIH).

ratios. In some experiments, either anti-HLA class I (W6/32: mouse IgG2a) or anti-HLA-DR (L243: mouse IgG2a) monoclonal antibody was added to the wells at a dose of $20 \mu \mathrm{g} / \mathrm{ml}$ at the start of the assay.

Cold inhibition assay. The specificity of EZH2 peptidestimulated CTLs was confirmed by a cold inhibition assay. In brief, ${ }^{51} \mathrm{Cr}$-labeled target cells $\left(2 \times 10^{3}\right.$ cells/well $)$ were cultured with the CTLs $\left(4 \times 10^{4}\right.$ cells/well) in 96-round-well plates with $2 \times 10^{4}$ cold target cells. T2 cells that were pre-pulsed with either the HIV peptide or a corresponding EZH2 peptide were used as cold targets.

Statistics. The statistical significance of the data was determined using a two-tailed Student's t-test. A p-value of $<0.05$ was considered to be statistically significant.

\section{Results}

IgGs reactive to EZH2-derived peptides. We prepared 12 kinds of EZH2-derived peptides based on their binding affinity to the HLA-A*0201 molecules (Table I). We first screened EZH2derived peptide candidates that can be recognized by the humoral immune system in cancer patients for the following reasons. First, we previously reported that IgGs reactive to peptides derived from cancer-associated antigens were frequently detectable in prostate cancer patients $(13,17,18)$. Second, the assay for peptide-specific IgG is much simpler and easier than the in vitro sensitization experiment to induce peptide-specific CTLs in cases in which only a limited number of PBMCs are available. Therefore, we determined whether IgGs reactive to each of the $12 \mathrm{EZH} 2$-derived peptides could be detected in the plasma of 20 prostate cancer patients 
Table II. EZH2 peptide-specific IgG in the plasma of prostate cancer patients.

\begin{tabular}{|c|c|c|c|c|c|c|c|c|c|c|c|c|}
\hline \multirow[t]{2}{*}{ Patient } & \multicolumn{12}{|c|}{ EZH2 peptide } \\
\hline & $48-56$ & $95-104$ & $120-128$ & $165-174$ & $222-230$ & $438-446$ & $569-577$ & $661-669$ & $665-674$ & $668-677$ & $699-708$ & $729-737$ \\
\hline & \multicolumn{12}{|c|}{ Immunofluorescence intensity } \\
\hline 1 & - & - & - & - & - & - & - & 129 & 184 & - & - & - \\
\hline 2 & - & - & - & - & - & - & - & - & 127 & - & - & - \\
\hline 3 & - & - & - & - & - & - & - & - & 186 & - & - & - \\
\hline 4 & - & - & - & - & - & - & 394 & - & 74 & - & - & - \\
\hline 5 & - & - & - & - & - & - & 464 & - & 89 & - & - & - \\
\hline 6 & - & - & - & - & - & - & - & - & 95 & - & - & - \\
\hline 7 & - & - & - & - & - & - & - & - & 114 & - & 56 & - \\
\hline 8 & - & - & - & 55 & - & - & - & - & 118 & - & - & - \\
\hline 9 & - & - & - & 343 & - & - & - & - & 76 & 63 & - & - \\
\hline 10 & - & 163 & 53 & - & - & - & - & - & 131 & - & - & - \\
\hline 11 & 204 & - & 395 & 214 & 100 & - & 320 & - & 1482 & 282 & 233 & - \\
\hline 12 & - & - & 209 & - & - & - & & - & 123 & - & - & - \\
\hline 13 & 65 & - & 169 & 243 & - & - & 95 & - & 214 & - & 239 & - \\
\hline 14 & - & - & - & - & - & - & - & - & 152 & - & - & - \\
\hline 15 & - & - & - & - & - & - & - & - & 229 & - & - & - \\
\hline 16 & - & - & - & - & - & - & - & - & 168 & - & - & - \\
\hline 17 & - & - & - & 67 & - & - & - & - & 240 & - & - & - \\
\hline 18 & 222 & - & 118 & 187 & 146 & - & - & - & 1675 & 195 & 204 & 124 \\
\hline 19 & 217 & - & 329 & 544 & 56 & 102 & 236 & - & 657 & 113 & 280 & - \\
\hline 20 & - & - & - & 56 & - & - & - & - & 126 & - & - & - \\
\hline Total & $4 / 20$ & $1 / 20$ & $6 / 20$ & $8 / 20$ & $3 / 20$ & $1 / 20$ & $5 / 20$ & $1 / 20$ & $20 / 20$ & $4 / 20$ & $5 / 20$ & $1 / 20$ \\
\hline
\end{tabular}

An IgG reactive to a corresponding peptide was judged to be positive when the immunofluorescence intensity in 1:100-diluted plasma was $>50$ times higher than that of a peptide-unloaded negative control. Only the positive results are shown.

Table III. Induction of EZH2 peptide-specific CTLs from the PBMCs of of HLA-A2 ${ }^{+}$prostate cancer patients.

\begin{tabular}{|c|c|c|c|c|c|c|c|c|}
\hline \multirow[b]{2}{*}{ Patient } & \multirow[b]{2}{*}{ HLA-A2 genotype } & \multicolumn{6}{|c|}{ EZH2 peptide } & \multirow[b]{2}{*}{ Flu } \\
\hline & & $120-128$ & $165-174$ & $569-577$ & $665-674$ & $699-708$ & $95-104$ & \\
\hline & & \multicolumn{7}{|c|}{$\mathrm{IFN}-\gamma(\mathrm{pg} / \mathrm{ml})$} \\
\hline 21 & 0201 & 272 & 241 & 0 & 0 & 0 & 0 & 0 \\
\hline 22 & 0207 & 236 & 0 & 0 & 0 & 127 & 0 & 236 \\
\hline 23 & 0201 & 168 & 270 & 0 & 0 & 0 & 0 & 325 \\
\hline 24 & 0207 & 3367 & 90 & 0 & 0 & 0 & 0 & 438 \\
\hline 25 & 0201 & 2339 & 179 & 137 & 0 & 0 & 133 & 574 \\
\hline 26 & 0207 & 2055 & 60 & 0 & 0 & 0 & 0 & 1073 \\
\hline 27 & 0201 & 0 & 181 & 0 & 0 & 0 & 0 & 734 \\
\hline 28 & 0207 & 0 & 0 & 0 & 0 & 0 & 0 & 53 \\
\hline 29 & 0206 & 0 & 0 & 0 & 0 & 0 & 0 & 0 \\
\hline 30 & 0206 & 0 & 81 & 53 & 0 & 0 & 0 & 0 \\
\hline Total & & $6 / 10$ & $7 / 10$ & $2 / 10$ & $0 / 10$ & $1 / 10$ & $1 / 10$ & $7 / 10$ \\
\hline
\end{tabular}

The PBMCs from HLA-A2+ prostate cancer patients were stimulated in vitro with the indicated EZH2 peptide as described in the Materials and methods. On day 15, the cultured PBMCs were tested for their reactivity to T2 cells, which were pre-pulsed with the corresponding EZH2 peptide or the HIV peptide. The values represent the mean of 4 wells, and the background IFN- $\gamma$ production in response to the HIV peptide was subtracted. The values which showed $>50 \mathrm{pg} / \mathrm{ml}$ and $\mathrm{P}<0.05$ by Student's t-test were judged to be positive. 
A
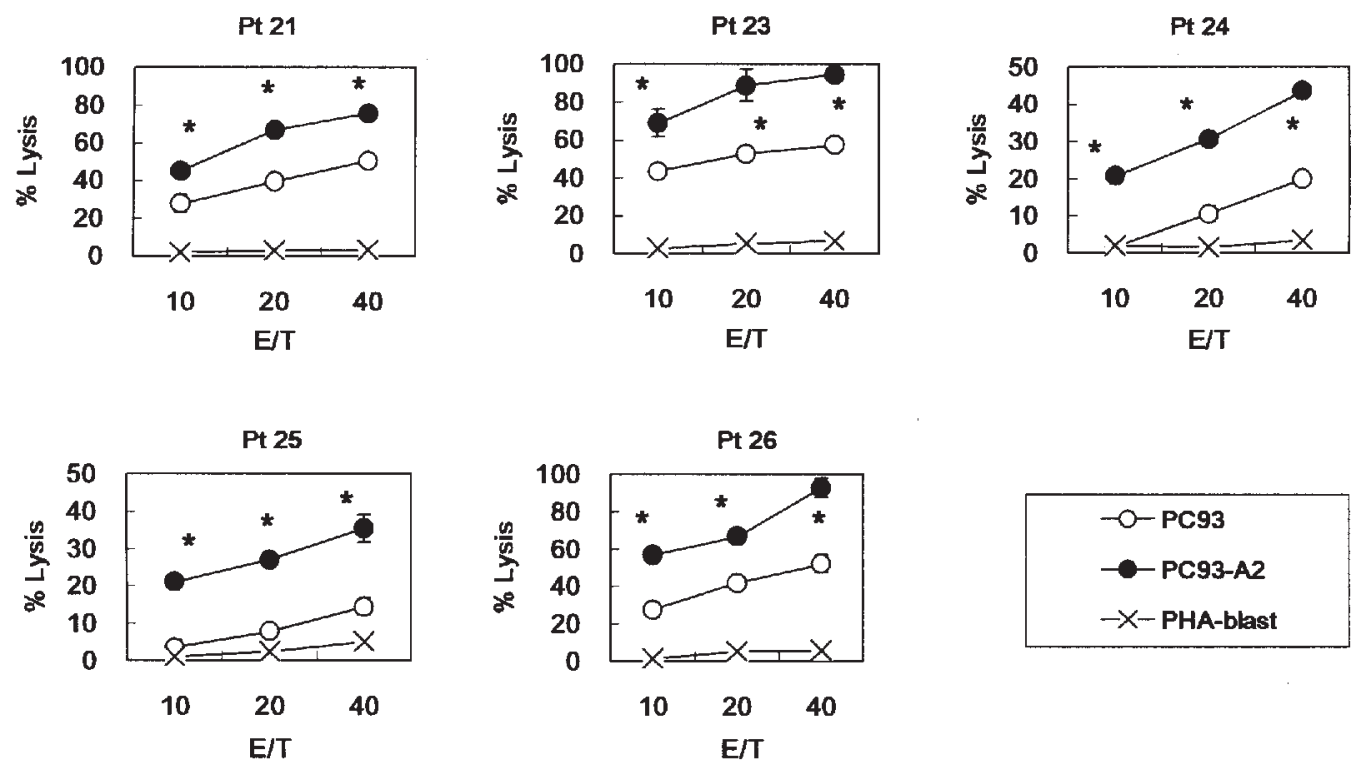

B

Pt 23

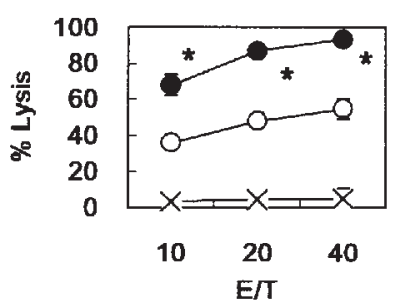

Pt 27

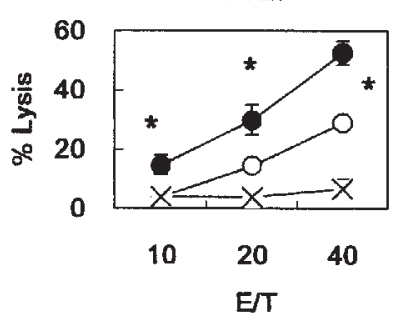

Pt 25

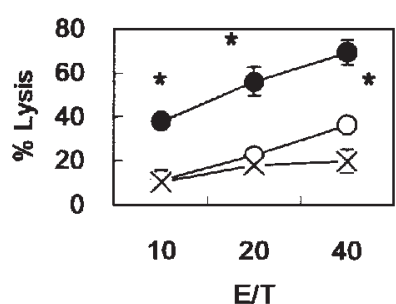

Pt 30

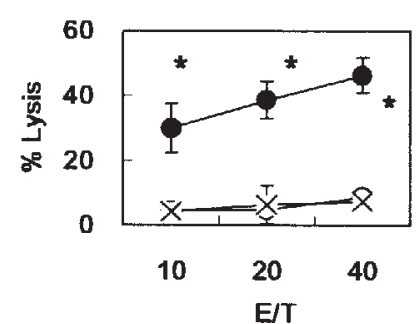

Pt 26
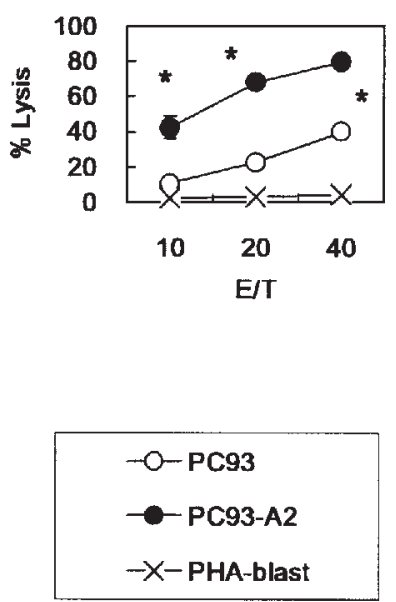

Figure 1. Cytotoxicity of EZH2 peptide-stimulated PBMCs from prostate cancer patients. CD8 ${ }^{+} \mathrm{T}$ cells from the PBMCs of 5 HLA-A2 $2^{+}$prostate cancer patients which were stimulated in vitro with each of the EZH2 120-128 (A) and EZH2 165-174 (B) peptides were tested for their cytotoxicity toward 3 different targets by a $6-\mathrm{h}{ }^{51} \mathrm{Cr}$-release assay. ${ }^{*}$ Statistically significant at $\mathrm{P}<0.05$.

(Table II). The levels of peptide-specific IgG were determined by using the Luminex method (15). These patients were not limited to the HLA-A2 ${ }^{+}$subjects, because the peptide-specific IgGs were not restricted to MHC class I molecules, as reported previously (19). An IgG reactive to a corresponding EZH2 peptide was judged to be positive when the immunofluorescence intensity in a 1:100-diluted plasma was more than 50 times higher than that of a peptide-unloaded negative control. As a result, IgGs reactive to the EZH2 120-128, 165$174,569-577,665-674$, and 699-708 peptides were detected in the plasma of $6,8,5$, and 5 of 20 patients, respectively. These 5 EZH2 peptides were recognized by IgGs more efficiently than the other 7 EZH2 peptides, and were employed in the following assays of CTLs.

Induction of EZH2 peptide-specific CTLs from cancer patients. We next determined whether or not these $5 \mathrm{EZH} 2$ peptides had the potential to generate peptide-specific CTLs from the PBMCs of 10 HLA-A2+ cancer patients (Table III). Their HLA-A2 genotypes were determined, and are shown in 
A
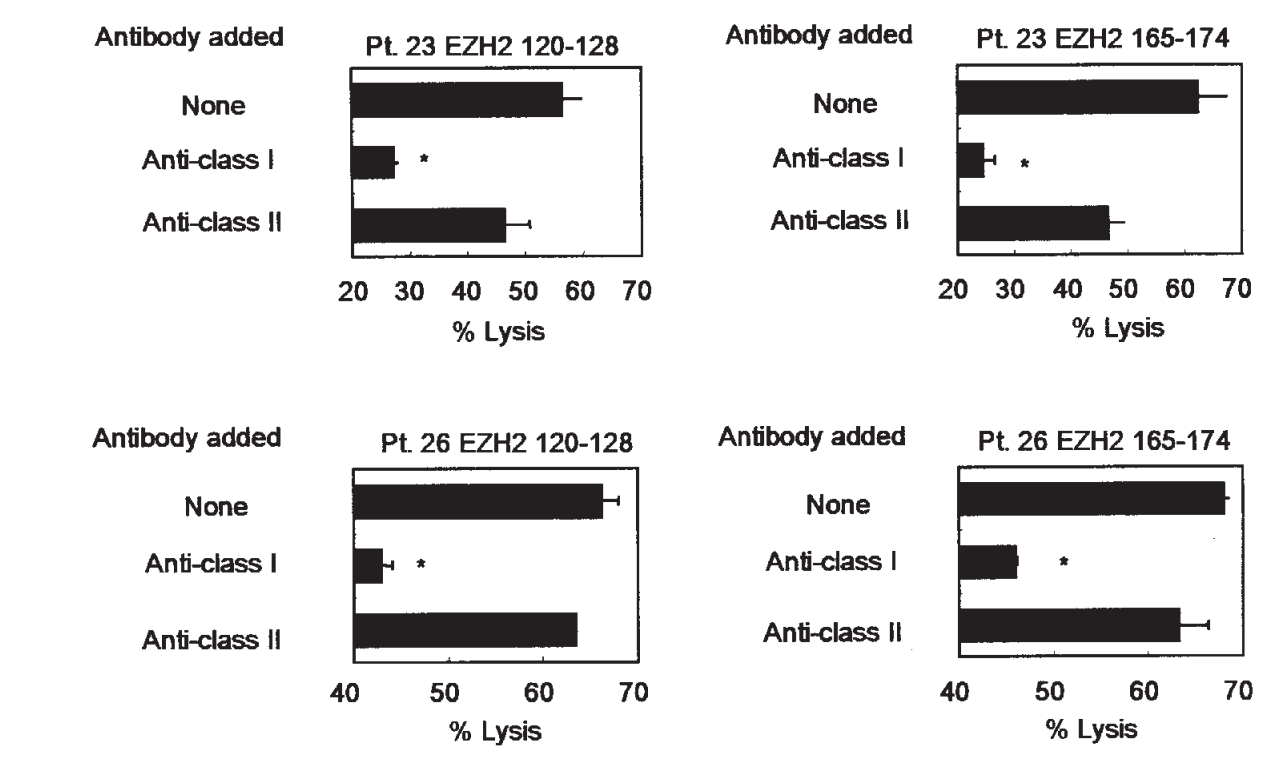

B
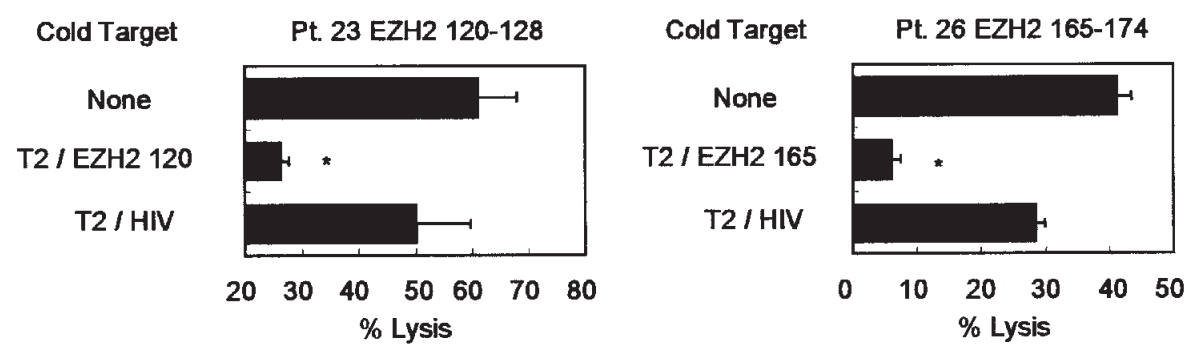

Figure 2. Peptide-specific and $\mathrm{CD}^{+} \mathrm{T}$ cell-dependent cytotoxicity of EZH2 peptide-stimulated PBMCs from prostate cancer patients. (A) CD8 ${ }^{+} \mathrm{T}$ cells from EZH2 peptide-stimulated PBMCs of 2 patients were tested for their cytotoxicity against the PC93-A2 cells. A 6-h cytotoxicity assay was performed in the presence of the indicated monoclonal antibodies. The assay was performed at an effector/target ratio of $10 / 1$. $^{*}$ Statistically significant at $\mathrm{P}<0.05$. (B) $\mathrm{CD} 8+$ T cells from EZH2 peptide-stimulated PBMCs of 2 patients were tested for their cytotoxicity against the PC93-A2 cells in the presence of unlabeled T2 cells, which were pre-loaded with either the corresponding EZH2 peptide or the HIV peptide. The assay was performed at an effector/target ratio of 10/1. *Statistically significant at $\mathrm{P}<0.05$.

the table. The EZH2 95-104 peptide was employed as a control that was recognized by $\mathrm{IgG}$ less frequently. The PBMCs were stimulated in vitro with each of the EZH2 peptides and examined for their IFN- $\gamma$ production in response to the corresponding peptide-pulsed T 2 cells. The assay was carried out in 4 wells, and the values that showed $>50 \mathrm{pg} / \mathrm{ml} \mathrm{IFN-} \gamma$ production, compared to the control, and $\mathrm{P}<0.05$ by the Student's t-test were considered to be positive. The result was that the EZH2 120-128 and EZH2 165-174 peptides induced peptide-specific CTLs in 6 and 7 of 10 cancer patients, respectively, and the induction efficiency was at the same level as that of the control Flu peptide. The EZH2 120-128 peptide induced peptide-specific CTLs from HLA-A*0201 and HLA-A*0207 patients, and the EZH2 165-174 peptide induced peptide-specific CTLs from HLA-A*0201, HLAA*0207, and HLA-A*0206 patients. The other EZH2 peptides induced peptide-specific CTLs less efficiently. The EZH2 95-104 peptide induced peptide-specific CTLs in 1 of 10 cancer patients. These results indicate that both the EZH2 120-128 and EZH2 165-174 peptide have the potential to effectively induce peptide-specific CTLs from HLA-A2 ${ }^{+}$prostate cancer patients.

Peptide-specific and $C D 8^{+} T$ cell-dependent cytotoxicity of EZH2 peptide-stimulated PBMCs. We next determined whether CTLs which were induced by the EZH2 120-128 and EZH2 165-174 peptides could show cytotoxicity against prostate cancer cells. To confirm their HLA-A2-restricted cytotoxicity, we utilized a PC93 prostate cancer cell line and its HLA-A2transfectant, PC93-A2 (13). In addition, purified CD8 ${ }^{+} \mathrm{T}$ cells from peptide-stimulated PBMCs were used for the cytotoxicity assay. As a result, the EZH2 120-128 peptide-stimulated PBMCs which were induced from 5 patients (no. 21, 23, 24, 25, and 26) showed a higher level of cytotoxicity against PC93-A2 cells than against PC93 cells (Fig. 1A). The EZH2 165-174 peptide-stimulated PBMCs which were induced from 5 patients (no. 23, 25, 26, 27, and 30) showed a higher level 
of cytotoxicity against PC93-A2 cells than against PC93 cells (Fig. 1B). In both cases, the levels of cytotoxicity against HLA-A2 positive PHA-stimulated T cell blasts were low or negligible.

We further tried to confirm which effector cells were responsible for the cytotoxicity. The cytotoxicity of $\mathrm{CD}^{+} \mathrm{T}$ cells from PBMCs of 2 prostate cancer patients (no. 23 and 26), which were stimulated in vitro with each of the EZH2 120-128 and EZH2 165-174 peptides, against the PC93-A2 cells was significantly inhibited by the addition of anti-class I mAb, but not by the addition of anti-class II (anti-HLA-DR) (Fig. 2A). In addition, the cytotoxicity of these EZH2 peptide-stimulated PBMCs against the PC93-A2 cells was significantly suppressed by the addition of the relevant EZH2 peptide-pulsed unlabeled T2 cells, but not by the addition of the HIV peptide-pulsed unlabeled T2 cells. Collectively, the results of these antibody blocking and cold inhibition assays indicated that the cytotoxicity of these EZH2 peptide-stimulated PBMCs was mainly ascribable to peptide-specific and HLA-A2-restricted CD8 ${ }^{+}$ $\mathrm{T}$ cells.

\section{Discussion}

Immunotherapy could be a novel therapeutic modality for the treatment of prostate cancer $(2,3)$. In recent years, our group has identified a panel of epitope peptides that are able to generate prostate cancer-reactive CTLs from prostate cancer patients $(13,17,18)$. Nevertheless, we have been searching for more useful peptide candidates for peptide-based immunotherapy against prostate cancer. In this study, we focused on the recently identified EZH2 protein, because this protein is overexpressed in metastatic prostate cancer (4) and is suggested to be a tumor-associated antigen (10). These lines of evidence indicate that EZH2 could be a good target for the development of a specific immunotherapy against prostate cancer. We previously identified EZH2-derived peptide epitopes which can be useful for the treatment of HLA-A24+ prostate cancer patients (11). In this study, we further attempted to identify EZH2-derived peptides that have the potential to generate cancer-reactive CTLs in HLA-A2 ${ }^{+}$prostate cancer patients because of the higher worldwide frequency of this allele (12). As a result, we identified two new EZH2-derived peptides, the EZH2 120-128 and EZH2 165-174. Although a different EZH2-derived peptide having the potential to induce HLAA2-restricted CTLs has been identified recently (10), these two new EZH2 peptides are potentially useful in specific immunotherapy for HLA-A2 ${ }^{+}$prostate cancer patients.

We first investigated whether or not IgGs against $12 \mathrm{EZH} 2$ peptide candidates would be detectable in the plasma of prostate cancer patients for the following reasons. First, we previously reported that $\mathrm{IgGs}$ reactive to peptides derived from cancer-associated antigens were frequently detectable in prostate cancer patients $(13,17,18)$. Second, the assay for peptide-specific $\mathrm{IgG}$ is much simpler and easier than the in vitro sensitization experiment to induce peptide-specific CTLs when the availability of a patient's PBMCs is limited. In this study, after screening CTL-directed peptide candidates by their ability to be recognized by IgGs, the 5 selected EZH2-derived peptides were further examined for their ability to induce peptidespecific CTLs from the PBMCs of prostate cancer patients.
As a consequence, the EZH2 120-127 and EZH2 165-174 peptides were found to be good candidates for peptide-based vaccine for HLA-A2+ prostate cancer patients. This result means that these two peptides were recognized efficiently by both the cellular and the humoral immune system. Interestingly, the induction of IgGs reactive to vaccinated peptides was positively correlated with longer survival of patients with advanced lung or gastric cancer $(20,21)$. In addition, the induction of IgGs reactive to the administered peptides was also correlated with a clinical response among patients with recurrent gynecologic cancer (22). Therefore, vaccination with the EZH2 120-128 and EZH2 165-174 peptides into HLA-A $2^{+}$prostate cancer patients could efficiently elicit the induction of both prostate cancer-reactive CTLs and peptidespecific IgG, and subsequently lead to clinical responses. We recently observed that peptide vaccination with a 9-mer peptide could induce peptide-specific and HLA-DR-restricted CD4 ${ }^{+}$ $\mathrm{T}$ cells in vivo (23). Such $\mathrm{CD} 4^{+} \mathrm{T}$ cells may participate in the augmentation of peptide-specific humoral responses in vaccinated patients. However, we do not yet have a clear understanding of the roles played by peptide-specific IgGs in anti-tumor immune responses. Further study could shed light on this matter.

We identified two EZH2-derived peptides that have the potential to generate cancer-reactive CTLs in HLA-A2 ${ }^{+}$ prostate cancer patients. Most Caucasians are HLA-A*0201positive, but HLA-A2 subtypes vary considerably in Japanese (12). EZH2-derived peptides were prepared based on the binding motif to HLA-A*0201 molecules (14), and HLAA*0201 molecule-expressing T2 cells were used for assays in this study. As a consequence, two EZH2 peptide candidates were found to effectively induce HLA-A2-restricted and tumor-reactive CTLs from patients with several HLA-A2 subtypes, including HLA-A*0201 and HLA-A*0207. The EZH2 165-174 peptide induced peptide-specific CTLs from an HLA-A* $0206^{+}$prostate cancer patient. Therefore, two newly identified EZH2 peptides could be applicable for the immunotherapy of a vast majority of prostate cancer patients with different HLA-A2 subtypes. This information might increase the possibility of treating HLA-A2 ${ }^{+}$prostate cancer patients using peptide-based immunotherapy.

\section{Acknowledgments}

This study was supported in part by Grants-in-Aid (KAKENHI) from the Ministry of Education, Science, Sport, Culture and Technology of Japan (no. 17016074 to K.I., and no. 18591449 to M.H.), from the Research Center of Innovative Cancer Therapy of the 21st Century COE Program for Medical Science (to K.I.), and from the Ministry of Health, Labor and Welfare, Japan (no. 15-17 to M.H.).

\section{References}

1. Greenlee RT, Murray T, Bolden S and Wingo PA: Cancer statistics 2000. CA Cancer J Clin 50: 7-33, 2000.

2. Harada M, Noguchi M and Itoh K: Target molecules in specific immunotherapy against prostate cancer. Int J Clin Oncol 8: 193-199, 2003.

3. Marrari A, Iero M, Pilla L, Villa S, Salvioni R, Valdagni R, Parmiani G and Rivoltini L: Vaccination therapy in prostate cancer. Cancer Immunol Immunother 56: 429-445, 2007. 
4. Varambally S, Dhanasekaran SM, Zhou M, Barrette TB, Kumar-Sinha C, Sanda MG, Ghosh D, Pienta KJ, Sewalt RGAB, Oyye AP, Rubin MA and Chinnaiyan AM: The polycomb group protein EZH2 is involved in progression of prostate cancer. Nature 419: 624-629, 2002.

5. Laible G, Wolf A, Dorn R, Reuter G, Nislow C, Lebersorger A, Popkin D, Pillus L and Jenuwein T: Mammalian homologue of the Polycomb-group gene Enhancer of zeste mediates gene silencing in Drosophila heterochromatin and at S. cerevisiae telomeres. EMBO J 16: 3219-3232, 1997.

6. Kleer CG, Cao Q, Varambally S, Shen R, Ota I, Tomlins SA, Ghosh D, Sewalt RGAB, Otte AP, Hayes DF, Sabel MS, Livant D, Weiss SJ, Rubin MA and Chinnaiyan AM: EZH2 is a marker of aggressive breast cancer and promotes neoplastic transformation of breast epithelial cells. Proc Natl Acad Sci USA 100: 11606-11611, 2003.

7. Jacobs JJ, Kieboom K, Mario S, DePinho RA and van Lohuizen M: The oncogene and Polycomb-group gene bmi-1 regulates cell proliferation and senescence through the ink4a locus. Nature 397: 164-168, 1999.

8. Jacob JJ, Scheijen B, Voncken JW, Kieboom K, Berns A and van Lohuizen M: Bmi-1 collaborates with c-Myc in tumorigenesis by inhibiting c-Myc-induced apoptosis via INK4a/ARF. Genes Dev 13: 2678-2690, 1999.

9. Vire E, Brenner C, Deplus R, Blanchon L, Fraga M, Didelot C, Morey L, van Eynde A, Bernard D, van der Winden JM, Bollen M, Esteller M, Di Croce L, de Launoit Y and Fuks F: The polycomb group protein EZH2 directly controls DNA methylation. Nature 439: 871-874, 2006.

10. Steele JC, Torr EE, Noakes KL, Kalk E, Moss PA, Reynolds GM, Hubscher SG, van Lohuizen M, Adams DH and Young LS: The polycomb group proteins, BMI-1 and EZH2, are tumourassociated antigens. Br J Cancer 95: 1202-1211, 2006.

11. Ogata R, Matsueda S, Yao A, Noguchi M, Itoh K and Harada M: Identification of polycomb group protein enhancer of zeste homolog 2 (EZH2)-derived peptides immunogenic in HLAA24+ prostate cancer patients. Prostate 60: 273-281, 2004.

12. Imanishi $T$, Akazawa $T$ and Kimura A: Allele and haplotype frequencies for HLA and complement loci in various ethnic groups. In: HLA 1991. Tsuji K, Aizawa M and Sasazuki T (eds). Vol. 1. Oxford Scientific Publications, Oxford, pp1065-1220, 1992.

13. Matsueda S, Kobayashi K, Nonaka Y, Noguchi M, Itoh K and Harada M: Identification of new prostate stem cell antigenderived peptides immunogenic in HLA-A2 $2^{+}$patients with hormone-refractory prostate cancer. Cancer Immunol Immunother 53: 479-489, 2004 .
14. Parker KC, Bednarek MA and Coligan JE: Scheme for ranking potential HLA-A2 binding peptides based on independent binding of individual peptide side-chains. J Immunol 152: 163-175, 1994.

15. Komatsu N, Shichijo S, Nakagawa M and Itoh K: New multiplexed flow cytometric assay to measure anti-peptide antibody: a novel tool for monitoring immune responses to peptides used for immunization. Scand J Clin Lab Invest 64: $1-11,2004$.

16. Hida N, Maeda Y, Katagiri K, Takasu H, Harada M and Itoh K: A new culture protocol to detect peptide-specific cytotoxic $\mathrm{T}$ lymphocyte precursors in the circulation. Cancer Immunol Immunother 51: 219-228, 2002.

17. Harada M, Kobayashi K, Matsueda S, Nakagawa M, Noguchi M and Itoh K: Prostate-specific antigen-derived epitopes capable of inducing cellular and humoral responses in HLA-A24+ prostate cancer patients. Prostate 57: 152-159, 2003.

18. Kobayashi K, Noguchi M, Itoh K and Harada M: Identification of a prostate-specific membrane antigen-derived peptide capable of eliciting both cellular and humoral immune responses in HLA-A24+ prostate cancer patients. Cancer Sci 94: 622-627, 2003.

19. Kawamoto N, Yamada A, Ohkouchi S, Maeda T, Tanaka S, Hashimoto T, Saijo Y, Saijo S, Nukiwa T, Shichijo S, Aizawa H and Itoh K: IgG reactive to CTL-directed epitopes of selfantigens is either lacking or unbalanced in atopic dermatitis patients. Tissue Antigens 61: 352-361, 2003.

20. Mine T, Gouhara R, Hida N, Imai N, Azuma K, Rikimaru T, Katagiri K, Nishikori M, Sukehiro A, Nakagawa M, Yamada A, Aizawa H, Shirouzu K, Itoh K and Yamana H: Immunological evaluation of CTL precursor-oriented vaccines for advanced lung cancer patients. Cancer Sci 94: 548-556, 2003.

21. Sato Y, Shomura H, Maeda Y, Mine T, Ueno Y, Akasaka Y, Kondo M, Takahashi S, Shinohara T, Katagiri K, Sato M, Okada S, Matsui K, Yamada A, Yamana H, Itoh K and Todo S: Immunological evaluation of peptide vaccination for patients with gastric cancer based on pre-existing cellular response to peptide. Cancer Sci 94: 802-808, 2003.

22. Tsuda N, Mochizuki K, Harada M, Sukehiro A, Kawano K, Yamada A, Ushijima K, Sugiyama T, Nishida T, Yamana H, Itoh $\mathrm{K}$ and Kamura $\mathrm{T}$ : Vaccination with pre-designated or evidence-based peptides for patients with recurrent gynecologic cancers. J Immunother 27: 60-72, 2004.

23. Harada M, Matsueda S, Muto A, Gohara R, Oda T, Iwamoto Y and Itoh K: In vivo evidence that peptide vaccination can induce HLA-DR-restricted CD4 ${ }^{+} \mathrm{T}$ cells reactive to a class I tumor peptide. J Immunol 172: 2659-2667, 2004. 